\title{
Disciplinary technologies of microfinance: fictitious proximity, visibility and surveillance in rural microfinance in Bangladesh
}

\author{
Dr. A H M Belayeth Hussain \\ Centre for Research on Women \& Gender (KANITA) \\ Universiti Sains Malaysia (USM), Malaysia \\ Email: belayeth@usm.my; belayeth-soc@sust.edu
}

\begin{abstract}
:
While microcredits are, by the development practitioners, repeatedly hailed as a useful measure of development policy, this empirical research in Bangladesh arrives at different results: the governing and disciplinary measures are necessary to trigger the best possible repayment success. Based on interviews with the microfinance beneficiaries, loan officers, and microfinance experts in Bangladesh, I chart some of the most frequently used governing and disciplinary techniques including fictitious proximity of loan officers, their fields of visibility and surveillance processes. The "success" of credit delivery is a neoliberal stance that ensures the ceaseless debt repayment process using the intentional and planned conduct, capitalizing social capital and credit honour reputation, surveillance over business enterprises, use of equivocal language and different forms of deception. The development strategy through microfinance in Bangladesh is a development "dispositif" with a changing shift in its declared social missions.
\end{abstract}

Keywords: Microfinance, disciplinary power, governmental power, neoliberalism, Bangladesh 
For more than forty years, Bangladesh has been an exemplary development model of Nongovernmental organizations (NGOs), which had the aim to target the communities and their social issues in rural areas. During the 1980s and 1990s, under the prescription of Structural Adjustment Policies, the reduction in public services and state spending, and the promotion of privatization and liberalization were accompanied by greater support for NGOs in Bangladesh by external development agencies (Brigg, 2006; Muhammad, 2009). Globally, in the developing world, this trend remained same- NGOs have taken the role of the state in delivering services that are compatible with the Washington Consensus reform programmes (Karim, 2011). The development ideas, such as empowerment, gender issues, and participatory development were in the gaze of development agencies and their overreliance on matrices and indices (Gardner and Lewis, 2015). Relying on the NGO activities, the microfinance institutions became commercial organizations and transformed their primary aim to achieve full financial sustainability and make profits quickly (Bateman, 2010). This process of commercialization of microfinance in Bangladesh started in the 1990s with a "new wave" of microfinance as opposed to the subsidized Grameen Bank model (Bateman, 2010). At the same time, when this "new wave" of microfinance became dominant in the developing world, social performance ${ }^{1}$ analysis of the financial institutions triggered the outreach and profitability issues.

To keep the mainstream development policy on the track, the state also took the initiative to gear up its financial institutions as well as to establish apex institution. Unlike India, where austerity policies of the government affected marginal people precariously to repay state debt (Bear, 2015) and mediate financial capital to the government welfare provisions (Kar, 2017), the Bangladesh government promoted its social safety nets particularly in the area of rural finance. The government and international donors had sponsored most of the NGO microfinance institutions, which later changed their not-for-profit organizational status to the concern of profitability and sustainability. This happened because subsidized institutions are not always able to remain financially self-sufficient (Bateman, 2010). During the 1990s, the neoliberal view of social performance had promoted non-subsidized, outreached, profitable and financially sustainable microfinance institutions. I agree that the neoliberalism is not a single coherent project, but an assemblage of techniques and institutional structures (Collier 2009; Ong 2007; MurrayLi 2007; Shore and Wright 1997; Shore, Wright and Pero 2011; cited in Bear, 2015). Unlike the state microfinance industry, which yet reports more than 90 percent repayment success, most of the NGO based microfinance programmes claim approximately 99 percent debt repayment rates. The overall expansion and outreach of microfinance institutions largely depend on their organizational portfolio and repayment success, which in many instances influence loan officers to apply coercive mechanisms and pressure for the regular repayment of debt. Recently, in Bangladesh and India in particular, researchers and media have accused some of the MFIs that repeatedly apply coercive measures in getting debt repayment, which has even resulted in suicide in India (Sriram, 2010), organ selling in Bangladesh (BDNews24, 2013) and compromise of borrowers' overall wellbeing (Hussain, 2010). The literature claims that microfinance has lost its moral compass not only due to its deviation from the declared social mission but also because of its coercive nature including sexual harassment, violent threat, public humiliation, verbal abuse and seizer of borrowers' assets (Hulme and Maitrot, 2014; Karim, 2011). Although the victimhood of borrowers and their agency in microfinance programmes are narrowed under the waves of Washington consensus neoliberalism (Karim, 2011), the NGO goals were achieved primarily through compliance rather than through coercion. I agree with the earlier reason and argue that loan officers in microfinance programmes use disciplinary mechanisms rather than utilizing coercive measures.

A microfinance expert respondent, Anu Muhammad, reflected on my question why rural development had received so much attention in development practices. He said, "declaration of the Women's Decade (1975-1985) by the United Nations and McNamara's speech on the situation of rural poverty had prompted the shift of fight against poverty. As a result, many NGOs had increased their global attention to the rural regions of the developing world. Considering these issues, NGOs and their women's issues

\footnotetext{
${ }^{1}$ Social performance measures are necessary to determine whether microfinance institutions are meeting the social goals set out in their missions. For more, see: microfinancegateway.org
} 
can be revealed as a global shift." The rationality of the need for rural development, women empowerment and so forth gave rise to the discourse of microfinance as a new form of dispositif (apparatus) in developing nations. Dispositif is an ensemble of forms that constitute development as a discursive formation, giving rise to an apparatus, which systematically relates knowledge and techniques of power (Escobar, 1995). In microfinance programmes, the process of subjectification through exercising power over female subjects (debtors) necessarily involves disciplining functions that begin with the enrolment of borrowers and the formation of credit groups; hence they act as monitoring, supervising and problem-solving body (Brigg, 2006). As an impact of the shifting development dispositif, the rapid growth of the number of borrowers in Bangladesh makes this a unique case in the global microfinance industry. As I mentioned, scholars consider this as a result of the shift of NGOs' initial aims of specific commitments about social issues to business-oriented policies of microfinance practices (Hulme and Maitrot, 2014; Kar, 2013; Muhammad, 2009).

I argue in this article that the conducts of loan officers and their borrowers forge a docility-utility relationship in microfinance. A microfinance group consists of village women and is based on peerselection, peer monitoring, peer-pressure and peer-support (Wenner, 1995; Sharma \& Zeller, 1998; Bayulgen, 2008). Despite delegated monitoring through joint liability, peer selection, and peer monitoring, microfinance loan officers have a unique role in shaping the conduct of microfinance borrowers. Furthermore, weekly meetings provide loan officers with the opportunity to monitor the borrowers closely to collect debt repayments and savings deposits. A microfinance borrower has to go through a rigorous screening and portfolio survey by a credit officer. Before allocating a loan to the borrower, the credit officer of the MFI assesses the default probability of an applicant using the information he has on the borrower, the lending group, the environment, and the predicted effectiveness of the MFI repayment incentives for this borrower (Godquin, 2004). Essentially, the subtle and tacit roles of loan officers constantly guide debtors and influence to conform to the norms of the institution. I intend to explore the loan officers' subtle and tacit conducts of governing aspects that guide the conducts of borrowers.

To explore governmental and disciplinary technologies in the microfinance practice, I aim to answer what roles do disciplinary (surveillance and training) and governmental (conduct of conduct and shaping subjectivities) power play as the technologies of discipline to ensure proper repayment of debt in state and NGO sponsored microfinance programmes. Based on seven months of fieldwork on rural microfinance in Sylhet (North-eastern division of Bangladesh) between 2012 and 2013, this article reveals the nature of disciplinary and governmental techniques used by the loan officers of the NGO $\left(\right.$ BRAC $\left.^{2}\right)$ and Government $\left(\mathrm{BRDB}^{3}\right)$ sponsored microfinance institutions. For this purpose, I conducted in-depth interviews of microfinance loan officers, their female borrowers and microfinance experts in Bangladesh. As a form of Foucault's connotation of the conduct of conduct ${ }^{4}$ (Gordon, 1991) that aims to shape, guide or affect the conduct of others I uncover how the loan officers constantly carry meticulous control over borrowers and assure subjection and impose them a docility-utility (Foucault, 1995) relation. This relation between the subjects (borrowers) and the dominators (loan officers) is the outcome of disciplinary technologies. I reveal the strategic relation of loan officers and borrowers, loan officers' technique of recording and reporting about borrowers, the technique of differentiating good and bad borrowers, technique of putting special attention to particular borrowers, and surveillance processes over borrowers' family and economic activities. While microfinance programmes, by the development practitioners, are repeatedly hailed as an effective measure of development policy, I arrive at the different result: a high extent of governing and disciplinary behaviours are present in microfinance programmes; hence financial successes are ensured through proper debt repayments.

\section{Fictitious proximity of loan officers}

\footnotetext{
${ }^{2}$ BRAC (formerly Bangladesh Rural Advancement Committee) is the largest NGO and one of the two biggest microfinance providers in Bangladesh.

${ }^{3}$ Bangladesh Rural Development Board (BRDB) is the flagship organization of rural financing.

${ }^{4}$ guide to conform an articulated set of behaviors on the basis of normative standards), or any attempt to shape human subjectivities with some deliberation (Dean, 2004).
} 
Two types of observations are utilized in microfinance programmes - lateral and hierarchical observations. As a lateral observation, delegated monitoring (Bond, 2004) activities in microfinance are done by borrowers and channeled to the loan officers where appropriate and necessary. It is the loan officer who supervises the credit performance of borrowers and ensures hierarchical observations, where the network of relations is reciprocal between supervisor and supervised. I analyze that the delegated monitoring activity done by borrowers themselves acts as a lateral observation, which channels the information about borrowers to the loan officers. In a hierarchical observation, the network of relations is a reciprocal entity between supervisor and supervised and originates from top to bottom, bottom to top, also laterally (Foucault, 1977). Therefore, to explore different channels of information and observation, I describe the nature of officer-borrower relations. I find that the loan officers apply, wherever appropriate, purposeful and deceived conducts to their borrowers. Regular relations and contacts between the loan officers and their borrowers are necessary to keep borrowers under proper surveillance. This ex-ante measure of discipline serves the purpose of protecting microfinance institutions against possible defaults.

I came to consume that constant contact of loan officers with borrowers is a fundamental element to make debtors more docile to the lending institutes. Most frequently, loan officers apply deliberate equivocation and different forms of deception to their borrowers as some of the basic techniques. There are also other forms of relationships that include formal routine relations, special relations with credit group leaders, threatening and creating vulnerability (as women's misconduct is synonymous to get social humiliation) through capitalizing on the credit-honour reputation of village women. I explore from the interviews that the most relevant aspect of officer-borrower relationships is regular reciprocal contacts. The lending institutes instruct their loan officers to make frequent contact with the borrowers and be spontaneous with them. During an interview, I asked a BRDB loan officer, Ms. Maharatna, about the nature of her behaviour to the borrowers:

Ms. Maharatna: Of course, there are some techniques which we learn during our training sessions. We learn 60 percent of these techniques from our training and reveal 40 percent of these techniques spontaneously from the field.

Belayeth Hussain: Does this technique work in debt repayment?

Ms. Maharatna: This is the best method; I have to be successful in the field. How can a loan officer collect debt repayment using force! This cannot be possible forcibly; a loan officer can only collect debt repayment establishing her close ties with borrowers.

The loan officers, who are "proxy creditors" (Kar, 2013), mediate creditor-debtor relationships in the process of credit delivery and debt repayment; therefore, the loan officers need to be in close and informal interactions with the borrowers (Kar, 2013). Loan officers find their system of thinking to guide and maneuver borrowers' conduct. In addition to loan officers' training, the BRDB officers employ different methods for creating the impression that they want to be closer to their borrowers. Loan officers put themselves into the position of a debtor, and a responsible creditor cannot collect debt repayment through applying any form of compulsion, Ms. Mahapatra adds. Loan officers think they must go beyond borrowers' daily lives and enter into their usual life events. Although the state does not intervene directly to the debtor's life, the microfinance programmes somehow create a process of financialization of daily life (Martin, 2002). A loan officer must be close to borrowers' family and then collecting debt would not be a difficult task for them, they believe. I find from the testimonies of loan officers that if a loan officer looks after a borrower very closely and intimately, she gets more regular repayment of debt. The loan officers, as proxy creditors, physically and emotionally integrate borrowers into microfinance system through creating new kind of socialities, obligations, and expectations in India, for instance (Kar, 2015). However, in Bangladesh, the loan officers' close and informal interactions are found fictitious proximity in microfinance practice. This type of proximity between the loan officers and their borrowers is found obvious in Ms. Jesmin's testimony, one afternoon during my interview in BRDB. She said, 
If a loan officer wants to get back money from a borrower, she must go inside into borrowers' mind. A debtor must realize that the loan officer is her closest one. I can give an example: "during the Sankranti festival [in the Bengali calendar], my borrowers seem to be very happy to preserve special Pita [handmade cake] for me even if I visit them after a week. They feel as if I am their closest one." If a loan officer keeps in touch with the borrowers and listens to the experiences of good and bad times, the borrowers consider their officers emotionally close. We do not threaten them; instead, we try to be intimate with them as a technique.

In BRDB, the loan officers fictitiously create the debt collection environment as an intentional system of conduct. However, sometimes, this form of conduct of conduct pushes MFIs into the mission drift that presses loan officers to deliver more credits and persuade borrowers to be involved with multiple MFIs and available mahajans ${ }^{5}$. In order to secure the MFI's recovery success, the loan officers persuade their borrowers to take loans from mahajans. People in rural areas have a negative impression about moneylender (mahajan) that resembles the loan officers' roles (Kar, 2013). However, I find that in their conducts, loan officers are not like a "bloodsucking" entity in microfinance programmes. The loan officers cannot be shadowed with local moneylenders because loan officers have the role of alienating the debt on behalf of their organizations. Sometimes loan officers recommend debtors be affiliated with other available lending institutes around them. In order to get the borrowers provisionally free from instalment backlog (women affiliate themselves with multiple MFIs that results in a large volume of unpaid instalments), the loan officers encourage their borrowers to take the loan from informal lenders available in their village. While borrowing from multiple lending institutes is a widespread practice in Bangladesh (Karim, 2011). It can also be seen as a "protectional microfinance" (Cox, 2013) in the sense that it helps poor women borrowers to manage irregularities of income for the time being.

Fictitious proximity (planned and intentional) of loan officers is also typical in BRAC microfinance. However, it is less evident in BRAC than the BRDB programmes. BRAC loan officers intentionally perform with borrowers depending on immediate needs. The field officers act in this way when they foresee (or see) borrowers' hidden or non-conforming behaviour. These forms of conducts are found fictitious and deliberate, and loan officers believe those relationships can foster repayment performance. Kar (2015) terms this close and informal interaction as emotional labour which is similar in the form of the loan officer's powerful affective ties created through everyday interactions to pressure women into regular payment. She argues, affectional pressure on borrowers obliges them to recognize their personal and intimate responsibilities to the loan officers rather than an impersonal legal obligation to the lending organizations. This is the general form of the art of government for the loan officers that they utilize in specific contexts. Of course, if a loan officer allows a borrower to share her good and bad times, the borrower feels closest to that officer. Since loan officers behave deliberately (purposefully and strategically), borrowers respond beyond questions because they feel near with the loan officers. This type of relationship is profound in the BRDB and BRAC programmes and have a positive impression on debt repayment performance.

In addition to intentional conducts, loan officers engage different deceptive activities aiming to shape borrowers' conduct in loan behaviour. This is also evident in both BRAC and BRDB programmes. However, it is more regular and typical in the BRDB microcredit programmes. The BRDB loan officers apply deception regarding the number of credit instalments and their due dates. Since most of the rural women do not have exact information about their loan disbursement date, the concerned loan officers pretend and inform their borrowers the false schedule of repayment. In particular cases, the concerned loan officers visit borrowers' homes at least one month before the actual repayment schedule- the officers collect credit instalments before the due date. If borrowers fail to repay, the officers tell them (at the end) that there is still one more month to pay the remaining instalments. The affected borrowers think their term has ended, but the loan officers know that the borrowers still have one month to go. The loan officers deceive their borrowers in another way- the BRDB borrowers have to repay one instalment monthly but are informed to pay fortnightly. On this issue, Ms. Maharatna, a BRDB loan

\footnotetext{
${ }^{5}$ Mahajans are informal lenders who offer credits to villagers with a high interest rate.
} 
officer, comments- "we do not disclose specific information to our borrowers. The due instalments must come back to me. If borrowers know our all tactics, they will consider them all in all. For my own sake, I do not inform them all facts."

In both lending institutes, the loan officers usually and frequently excuse to the borrowers in the name of their branch office. I find this excuse another type of deception to their borrowers because borrowers were guided to think if they do not repay in time, the loan officers will lose their jobs or senior officers will charge the loan officers. Loan officers rely on the relationality of debt to ensure the loan recovery (Kar, 2013). This relationality entails not only the powerful affectional ties (Kar, 2013) of loan officers but also different forms of deceptions to capitalize the obligations of affectional debt relationships. This type of trick is more common in the BRAC microfinance. The loan officers believe if they do not use false statements, they might not get proper loan recovery. This can be considered another technique which has been employed by BRAC loan officers as a systematic way of thinking about how to govern their borrowers. I term this type of deception to be another type of governmental rationality, which constantly and successfully guides borrowers' credit behaviour. By using this deception, the loan officers secure debt repayments without employing further intervention. This is not "social reckoning of state debt," rather a social reckoning of personal debt that develops conduct of microfinance instead of what Bear (2015) refers to as "conduct of productivity."

\section{Fields of visibility}

Strong social relationships among the villagers play a decisive role in assembling information about borrowers. It has two fundamental functions: ensuring the mutual responsibility of credit and the constant flow of information about borrowers. Although members of the credit group (samity ${ }^{6}$ ) serve this purpose, the managers and presidents of a samity perform the central role in this process. Using their social networks, the samity leaders classify the traits of an incumbent member (borrower). Therefore, in microfinance practice, the issue of permanent residency of a woman borrower is a prime concern before approving her as a group member. Social relation and the residence place of borrowers extends loan officers' visibility over borrowers. The lending institutes only approve loans to borrowers who are within the same clan or kinship and might be within the reach even if they flee from the village. Kar (2017) argues that, to secure the credit, lending organizations use kinship as a moral and relational obligation of repayment. In many programmes, lending institutes do not take collateral but approve the individual loan and ask borrowers for a male guarantor. On this type of occasion, the loan officers ask for joint photos (Kar, 2017) of borrowers and their husbands. The loan officers continuously monitor and manage the relations of guarantees through the use of photographic documentation, attention to family life, any possible disturbance to husband's income and event of death (Kar, 2017). MFIs always attempt to help borrowers and their kin to maintain good relationships that confirm the guarantee of relations. In addition to joint photos, I find the loan officers ask for the copy of national identity card of borrowers and their husbands. Although it is not coercive in microfinance, the means of observation that comes through gathering borrowers' information is the precondition (as an ex-ante measure) for exercising discipline. Getting close to each other borrowers guarantees information about a client and is valuable to the lending institutes. It is a general conception among borrowers in rural Bangladesh that staying closer brings prosperity for them. A leader of a borrowing group, Ms. Roy, reflected during the interview to my questions.

Belayeth Hussain: How do you value social relation in a smooth microfinance programme?

Ms. Roy: Staying closer is essential because if I face trouble my closest persons will come first and favour me. If I do not have good relations with them, no one comes to my home. If someone wants to stay with samaj, maintaining good relations with others is a must. Living without a good relationship with the neighbours is stupidity. If I have a tough time, my neighbours will come first, and others may come next.

\footnotetext{
${ }^{6}$ Association is called samity in Bangla. MFIs and their borrowers typically call their credit group samity.
} 
In the microfinance systems, the group leaders' responsibilities range from information collection for the MFIs to the management of the credit group. They are the principal managers of all activities of the group. Since all borrowers are from the same village, leaders know the best possible techniques of communicating with the borrowers. The loan officers instruct their group leaders to achieve better efficiency and performance: scrutinizing domicile of a prospective borrower, ability to handle the kisti ${ }^{7}$, and borrower's assets. Group leaders need to go to the borrowers' home through the muddy way in the rainy season just because the loan officers instruct them to collect money properly, a BRAC credit group leader adds. She says, "I suggest them to eat small fish instead of big ones. I tell them to utilize their loans properly and pay instalments in time. Then, I would be able to recommend the next loans for them." The reputation of the credit samity depends on the performance of the leaders. The members of a group expect and appreciate the strict performance of a leader. In her opinion, a BRAC samity president, with her high prestige, says:

We have a very strong samity. You may consider me a tiny lady, but no one in my samity will stay without paying the instalment. If members fall in trouble, they come to me and tell me the problem a day before our meeting is due. However, I do not agree and tell them- 'if you have only fifty Taka, I will give the rest.' I pay on behalf of them. I do not want to be dishonoured [chhuto howa].

Making borrowers dishonoured is critical in a rural locale. This is another type of technique to secure weekly credit instalments. Lending institutes prevent any possible default in the name of protecting women's honour and reputations in the village terrain. If a lady fails to repay instalments, the loan officers contact the village panchayat ${ }^{8}$ and other group members to resolve this issue. Since the rural elites administer the panchayat, female borrowers anticipate humiliation in instances of presenting misconduct before the panchayat. At worst, when the instalments remain unpaid, loan officers adjust them to the savings, insurance premiums and shares of the borrowers. The borrowers want their honour unquestioned within the village. This question of honour reputation is equally evident in BRAC and BRDB microfinance programmes. Karim (2011) shows how microfinance NGOs use existing social networks and concept of shame to enforce their repayments in a process she describes as "NGO governmentality'. However, I find this technique is also common in state-sponsored microfinance. Therefore, it is not only a technique of NGO governmentality but also a state governmentality per se. Any form of nonconformity to the norms of lending organizations results in interrogations to borrowers within and outside the credit-group meeting. To the villagers, those interrogations are a public humiliation for a village woman because they are culturally vulnerable in rural areas (Rahman, 1999). It is institutionalized in the village that those who repay the debt regularly have a better reputation in society. But those who experience real financial hardship cannot pay back without intervention, for example, some form of coercion. Therefore, loan officers need to prepare a platform for creating pressure on borrowers from cultural aspects. From the testimonies of loan officers, I found that creating a 'shame' for temporary default members is an effective means of securing timely repayment. This 'shame', which is a desirable attribute of rural women, is a loan recovery technology, which regulates female conduct and casts them aside should they break the norms of rural society (Karim, 2011). I think, however, that this attribute is found to be non-manifest until failure in repayment occurs as long as the debt repayment is concerned. The loan officers deliberately construct a situation of 'shame' as a technique of discipline, which has a similar tone to Karim's connotation of public humiliation as a disciplinary function. Ms. Jesmin, a loan officer, gave her testimony about an irregular borrower.

Ms. Jesmin: She [borrower] feels ashamed. This shame is good and positive for us; and, I deliberately make this shaming situation for her. We have to create a situation of shaming to achieve our goal [of debt collection].

Belayeth Hussain: Why do not you ask for the debt repayment privately?

\footnotetext{
7 The weekly debt repayment instalment is commonly known as kisti.

${ }^{8}$ Village Panchayat is an informal part of local government. The term 'Panchayat' has frequently been used to denote some form of indigenous system of local government. It means a non-official representative body (originally) consisting of five members (in literal meaning) dealing with local affairs.
} 
Ms. Jesmin: When loan officers create a shaming situation, they do it knowingly and intentionally. A loan officer asks a woman for the instalments in front of fellow group members. This has a clear advantage: if a loan officer asks this question in the group, a woman might feel dishonoured to other villagers. If field organisers ask this individually and separately, a client might defer the due date on the condition that the field staff shall not tell this issue to others. In some instances, a default borrower waits for other borrowers to pay first, which pushes the lending institute into a rotation and delay. Therefore, loan officers misinform a specific borrower and tell that other borrowers have already paid instalments.

Belayeth Hussain: Does this work?

Ms. Jesmin: Yes, this works fine, because other borrowers need further credit from the same lender. In any situation may arise, threatening the loss of honour and reputation of a borrower has a positive relationship to credit recovery. Clients are scared of losing their honour.

Belayeth Hussain: What do you do in case the borrower does not pay even you create a shaming?

Ms. Jesmin: If a client does not repay, other members create pressure on her. Sometimes, members go to that lady's family members (son, for example). They tell him - 'look boy, your mom did not pay samity's money'. As a result, her son creates pressure in the family. The son feels ashamed because some other people may imply that his mom is a bad lady.

This is also a useful technique which poses borrowers' deference to the loan officers. The techniques of shaming and deliberate non-disclosure about the quality of a borrower work well in both MFIs.

\section{Surveillance}

Three models of group-based micro lending grounded on moral hazards (Stiglitz, 1990), strategic default (Besley \& Coate, 1995) and adverse selection (Ghatak, 1999) are predominant in microfinance programmes. Therefore, collecting information about borrowers is of immense importance for controlling possible defaults and moral hazards. There are many methods, for example, through preparing activity reports of the borrowers, gathering information about their prospective and current investments, financial information of borrowers' families, and information about good and bad borrowers. In BRDB, loan officers do not prepare any formal activity report of their borrowers; rather their report through verbal means or written bookkeeping. They resolve the issues during weekly meetings. The officers regularly record a borrower's presence, savings, deposit instalments, and other group activities. A loan officer, Mr. Kalam, gave his opinion on the activity reporting:

The main focus is whether they are regular in debt repayment. We give them passbooks. We have also weekly collection sheets: one copy is for the samity and the other is for the office. We note down each aspect of financial information in the passbook: how much savings, share, instalments and interest have been deposited. We can easily identify default borrowers on the basis of tally marks we put in the collection sheet. We inform the branch manager about the debt repayment status.

For BRAC, major reporting functions are outsourced to the president, manager, and members of a credit group. However, the loan officers regularly have to report to the office about borrowers' activities. The passbook functions as a recording and reporting book in itself. The BRAC loan officers seem to be meticulous about passbook records, and they rely on this before giving further credits to a borrower. BRAC microfinance has a stricter follow-up system of their borrowers' activities. Anyone (notably, a new loan officer) can easily recognize any difficulty about a borrower. Furthermore, a loan officer has to follow through with a printed copy of a weekly information sheet and pass it on to their branch office. Then, the office puts all information on computer-assisted programmes. In some cases, the officers have to report to the branch office daily. Unlike BRDB, the BRAC loan officers focus on reporting to uncover 
good and bad borrowers. When the BRAC loan officers get information about any possible bad borrower, they prevent further loans and any trickle-down impact of the information to the rest of the borrowers. The loan officers do this in both microfinance programmes. According to loan officers, a good borrower of a group is a debtor who regularly communicates with the loan officers, attends weekly meetings regularly and runs her instalments and savings properly. Reflecting on my question- how do loan officers classify good and bad borrowers, Mr. Uddin, a BRAC loan officer said:

We have all information for each borrower. We have files for each village and samity. Our sir [branch manager] can see the documents and identify any particular borrower for any reason. We have pictures of borrowers and their husbands. We preserve the husband's picture because sometimes a husband refuses and says he did not take money from his wife. We fix one picture in the passbook, one in the account report and one in the admission file.

Since 2010, the BRAC programmes have had a new strategy to reward good borrowers based on a computer-assisted database. For this, the headquarters sends a monthly report to the local office about the regular borrowers who might have a chance to get new loans (top-up loans) even if they have an unfinished/outstanding debt. When the task of differentiating the quality of borrowers is complete, loan officers consider selected borrowers as the special cases. As a mechanism of examination (in Foucault's notion), considering each borrower an individual and special case serves as another function of observation. Foucault (1977) says that based on individuality, an individual may be described, judged and compared with others. I find that the microfinance institutions examine their borrowers by performance, make special cases for specific borrowers and assign special attentiveness to some of them. This practice of making borrowers special cases is a particular form of knowledge about the specific borrowers. Although the credit group leaders consider each borrower in the group alike, the loan officers impose specific conducts of leaders and urge for compliance with the norms of the lending organizations. The most common instruction given by the loan officers is: "If you do not follow the discipline, others will not conform to the norm of the organization.' The credit group leaders recognize that the loan officers' disciplinary instructions to the borrowers are very useful. Therefore, they receive, accept and welcome any special attentiveness by the loan officers. The borrowers see officers' regular visit to their homes as a natural and routine activity, and this works as an ex-ante measure in order to avoid potential defaults.

In addition, to assess the quality of borrowers, loan officers keep close eyes on borrowers' existing enterprise and potential business plan. In the process of hierarchical observation, surveillance over borrowers' enterprise and investment is a particular type of top-down observation. This surveillance secures the highest possible level of information about the status of borrowers' enterprise and investment. For the new loanees, officers conduct a pre-loan survey that assesses the feasibility of loan recovery. Obtaining information about current and prospective enterprises aids the primary surveillance procedures. Both lending institutes strictly monitor the useful investments and collect critical information about the borrowers, their enterprises and economic conditions of their families. After disbursing the credit to the borrowers, the loan officers of both lending organizations come to the particular enterprise and ascertain its viability that has the principal aim to ensure proper utilization of loan, which therefore guarantees the debt payment. Sometimes, the loan officers instruct their borrowers to change the businesses for making loan recovery process workable.

\section{Discipline through dispositif and panopticon?}

I had asked my expert interviewee, Anu Muhammad, why microfinance programmes are so successful in debt repayment. He said,

Lending organizations offer an emancipatory role to the rural people. Through this process, an individual or an organization becomes acceptable to poor people in rural society. It is practiced through hegemony of the persons (or organizations) who govern rural people in varied ways. In rural Bangladesh, cultural settings of the traditions and regulations produce a set of governmental situations for the powerful persons and 
organizations. In the process of productions and reproduction of cultural settings, individuals try to comply with them as if these governmental conditions bring benefits for their own. The rural poor consider microfinance institutions as the saviors because no one gives them a single penny to survive. This makes rural people submissive to the 'powerful' micro-lending organizations.

In some microfinance programmes, loan officers consider credit delivery "just a business" and do work for rural people "just a 10 percent" (Kar, 2013) of poverty reductions. Rural people do not consider an NGO a formal or professional microfinance institution; rather, they see it as a saviour organization that appears to support them. This relationship between the borrowers and the MFI loan officers is not perceived as one of the formal market relations. The interaction between NGO workers and borrowers are the logic of power (Karim, 2011) because credit is a collective, ethical, fiscal and political obligation that involve hidden socialities of economic life (Bear, 2015). This interaction makes people compliant to the lending institutes, and the poor want to be loyal and reliable to that institute. In this situation, a microfinance institution functions as a powerful presence over financially backward subjects. In a subtle way, an institution alike represents a part of the dispositif element. In fact, the conception of a saviour as a person or an organization develops through the cultural embeddedness of women's social roles. Rural women have a specific fear of the loss of their honour. This honour is also related to women's social network or social capital inside the village. They have strong bonding which they do not want to weaken due to loss of their honour or reputation. The microfinance institutions use this cultural situation of women and make them the principal target as a matter of convenience. Another expert respondent, Baki Khalily, said that "women empowerment is neither an outcome of microfinance programmes nor an expected, focused result. It is lending institute's matter of convenience. Later, when it became successful, the scholars and development practitioners claimed that it brought empowerment to women."

As per loan officers' testimonies, repayment performance is almost completely dependent on a situation where the "economy of shame" is functional. Although the presence of the economy of shame is thoroughly dealt by Lamia Karim (2011) in her analyses of Microfinance and its Discontents, I found this governmental technique of MFI loan officers is a meticulous way of forging women more efficiently, and the whole process is based on careful, intentional actions and prudence. Apart from that technique, concealing and disclosing a borrower's credit record functions effectively in repayment performance. Therefore, the three techniques - purposeful/strategic conduct of loan officers, social relations of women borrowers, and deceptive behaviour of loan officers are regarded as beneficial to the debt repayment. Additionally, threats of sanctions are found to be effective in increasing repayment performance. The credit groups with sanctions have more reciprocal relations and therefore have more additional credits (Anthony, 2005). Since sanctions are in different forms and come from different agencies, the threats of sanctions (formal administrative persons, police, and higher officials) have a surprisingly positive impact on credit recovery.

The importance of power in the history of the economy depends on the market economy and requires the production of docile bodies under certain cultural-physical conditions (Foucault, in Escobar, 1995). The microfinance delivers credits to rural women who are outside the range of the formal market scenario. The MFI's role as the saviour shows significant implications of symbolic violence ${ }^{9}$, which could be exerted as a kind of power in connection to the culture of giving and kindness (Bourdieu, 1977). This asymmetric relation of indebtedness creates personal loyalty, restrict debtor's freedom and force them to be cooperative through exercising durable power over them. And, this relation produces the submissiveness of female borrowers to the 'powerful' microfinance organizations.

The principal aim of microfinance is to deliver credit to a financially viable person and collect debt repayment successfully. The process of producing docile borrowers is the basic medium through which the loan officers can achieve the goals. Disciplinary technology aims to develop a docile body (Foucault, 1995). Some of the most frequently used governing techniques of microfinance loan officers are deliberate (intentional and planned) conducts, use of equivocal language and different forms of

\footnotetext{
${ }^{9}$ According to Bourdieu, where violence is symbolic, subjugated individuals and groups consider dominator's power to be natural.
} 
deception. However, there are other techniques, which seem to be quite useful- the threat of sanctions and the resulting loss of honour reputation. Information channels play a decisive role in shaping the financial discipline of borrowers. Among others, activity reports on borrowers' financial behaviour and surveillance over their business initiatives are mostly evident in lending institutions. The description of governing techniques as 'conduct of conduct' not only indicates the way loan officers govern their borrowers but also explores the correctness of borrowers in terms of conformity to the lending institutes. Additionally, the governing process exposes the 'rationality of government' in the sense that it tries to uncover the system of self-sustaining control of any potential default borrowers; hence the conduct of an individual borrower has been shaped in appropriate ways. Information channels are important for loan officers in which borrowers voluntarily involved in the flow of sensitive information about their life events. Activity reports, acquiring information about business initiatives and identifying good and bad performers are the most influential techniques through which the loan officers know how to guide borrowers' credit behaviour before, during and after loan terms. The form of delegated monitoring (Bond, 2004) is said to be outsourced monitoring because the borrowers receive, for their tasks, additional care from the loan officers. The microfinance institutions extend their panoptic gaze, which is one of the central mechanisms of the disciplinary power. According to Foucault (1995), surveillance rests both on the individual body and functions through a network of relationships. The microfinance institutions not only target female borrowers and their families but also exploit the social relations. In this process, borrowers are unable to know when the loan officers watch and monitor them. They only know that the information relevant to them is communicated through various channels.

The disciplinary aspect has been achieved by avoiding dysfunctional members on the basis of available sensitive information about prospective members, current members, and their enterprises. In this way through social capital, women's credit groups provide microfinance institutions with a mechanism for reducing their institutional transaction costs (administrative costs), motivating women for repayment and financial discipline among them (Rankin, 2006). For many reasons, including targeting women to give more credits, the state of the financial system becomes the principal objective of the microfinance institutions (Rankin, 2006; Rahman, 1999). In the practice of disciplinary power, a disciplinary mechanism functions like a microscope of conduct (Foucault, 1995). The microfinance institutions apply disciplinary apparatuses at their own convenience and apply them to meticulously observe their borrowers. The conduct of loan officers in shaping the conduct of borrowers not only explores the way of governing but also the propriety of borrowers to their lending institutes. The rationality of governmental procedures in loan officers' conduct works like a magic. I consider this rationality of governing as a system of self-sustaining control of possible and committed delinquency to the lending institutes. The loan officers' guided conduct inherently shapes borrowers' debt behaviour as submissive to and productive for the lending institutes. The process of debt repayment is the fundamental element to the financial sustainability of microfinance institutions. Further grants and investment, apart from the institution's portfolio, depending on social performance which emphasizes outreach, portfolio quality, profitability, efficacy and productivity, financial management, and diversity of the financial services. As a neo-liberal policy for both the government and NGOs, microcredit programs work to nurture a subjectivity of the "rational economic woman" that may function efficiently and sustainably in the domain of the market (Rankin, 2001). The success of credit delivery is a neoliberal stance of the government and NGOs; therefore, the development strategy through microfinance in Bangladesh is a development discourse with a changing shift in declared social missions. 


\section{References}

Anthony, Denise. 2005. "Cooperation in microcredit borrowing groups: identity, sanctions and reciprocity in the production of collective goods." American Sociological Reviews no. 70:496-515.

Bateman, M. 2010. Why doesn't microfinance work?: the destructive rise of local neoliberalism. London and New York: Zed Books.

Bayulgen, Oksan. 2008. "Muhammad Yunus, Grameen Bank and the Nobel Peace Prize: what political science can contribute to and learn from the study of microcredit." International Studies Review no. 10 (3): 525-547.

Bdnews24.com. 2013. "Khudro riner kisti shoodhe ongo bikri." Bdnews24.com, October 28, 2013.

Bear, Laura. (2015). Navigating Austerity: Currents of Debt along a South Asian River. Stanford University Press, California.

Besley, T., \& Coate, S. (1995). Group lending, repayment incentives and social collateral. Journal of Development Economics, 46(1), 1-18.

Bond, P., \& Rai, A. S. (2008). Cosigned vs. group loans. Journal of Development Economics, 85(1-2), 58-80. doi: 10.1016/j.jdeveco.2006.05.006

Bourdieu, P. (1977). Outline of a Theory of Practice. Cambridge: Cambridge University Press.

Brigg, Morgan. 2006. "Disciplining the developmental subject: neo-liberal power and governance through microcredit." In Microfinance: Perils and Prospects, edited by Jude L Fernando, 64-88. Oxon, New York: Routledge.

Cox, J. (2013), Microfinance and its Discontents: Women and Debt in Bangladesh L. Karim. Minneapolis and London: University of Minnesota Press, 2011. xxxiii + 241 pp., glossary, notes, index. Aust J Anthropol, 24: 218-219. doi:10.1111/taja.12044

Dean, Mitchell. 2007. Governmentality: power and rule in modern society. Reprinted ed. London: Sage.

Escobar, A. (1995). Encountering Development: The Making and Unmaking of the Third World. Princeton: Princeton University Press.

Foucault, M. (1977). Discipline and Punish: The Birth of Prison. New York: Vintage Books.

Foucault, M. (1995). Discipline and Punish: The Birth of Prison. New York: Vintage Books.

Gardner, Katy and Lewis, David (2015) Anthropology and development: challenges for the twenty-first century. Pluto Press, London

Ghatak, Maitreesh. 1999. "Group lending, local information and peer selection." Journal of Development Economics no. 60 (1): 27-50. doi: 10.1016/s0304-3878(99)00035-8.

Godquin, M. 2004. "Microfinance repayment performance in Bangladesh: how to improve the allocation of loans by MFIs." World Development no. 32 (11): 1909-1926. doi: 10.1016/j.worlddev.2004.05.011.

Gordon, Colin. 1991. "Governmental rationality: an introduction." In The Foucault Effect: Studies in Governmentality, edited by Colin Gordon Graham Burchell, Peter Miller, 318. Chicago: University of Chicago Press.

Hulme, David and Maitrot, Mathilde, Has Microfinance Lost its Moral Compass? (November 20, 2014). http://dx.doi.org/10.2139/ssrn.2560331

Hussain, A. H. M. B. (2010). Embodiment and Emotionality of Women Credit Clients: Scrutinizing Agency Constraints of BRAC Microcredit Clients in Sunamganj, Bangladesh. Asian Social Science, DOI: $10.5539 /$ ass.v6n11p3

Kar, Sohini. 2013. Recovering debts: Microfinance loan officers and the work of "proxy-creditors" in India. American Ethnologist. DOI: https://doi.org/10.1111/amet.12034 
Kar, Sohini. 2015. Austerity welfare: Social security in the era of finance. Anthropology Today. DOI: https://doi.org/10.1111/1467-8322.12378

Kar, Sohini. 2017. Relative indemnity: risk, insurance, and kinship in Indian microfinance. Journal of the Royal Anthropological Institute. DOI: https://doi.org/10.1111/1467-9655.12608

Karim, Lamia. 2011. Microfinance and its discontents: women in debt in Bangladesh. Minneapolis, University of Minnesota Press.

Martin, Randy. 2002 Financialization of Daily Life. Philadelphia: Temple University Press.

Muhammad, Anu. 2009. "Grameen and microcredit: a tale of corporate success." Economic \& Political Weekly no. XLIV (35): 35-42.

Rahman, A. (1999). Women and microcredit in rural Bangladesh : Anthropological Study of the Rhetoric and Realities of Grameen Bank Lending. Boulder, Colo.: Westview Press.

Rankin, K. N. (2001). Governing development: neoliberalism, microcredit, and rational economic woman. Economy and Society, 30(1), 18-37.

Rankin, K. N. (2006). Social Capital, Microfinance and the Politics of Development. In J. L. Fernando (Ed.), Microfinance: Perils and Prospects (pp. 89-111). Oxon, New York: Routledge.

Sriram, M. S. 2010. "Microfinance: a fairy tale turns into a nightmare." Economic and Political Weekly no. XLV (43): 10-13.

Stiglitz, J. E. 1990. "Peer monitoring and credit markets." World Bank Economic Review no. 4 (3): 351366. doi: 10.1093/wber/4.3.351.

Wenner, M. D. 1995. "Group credit: a means to improve information transfer and loan repayment performance." Journal of Development Studies no. 32 (2): 263-281. doi: 10.1080/00220389508422414.

Zeller, Manfred, and Manohar Sharma. 1998. Rural finance and poverty alleviation. Washington D.C: International Food Policy Research Institute (IFPRI). 